\title{
Influence of stocking density on production and water quality of a photo- heterotrophic intensive system of white shrimp (Penaeus vannamei) in circular lined grow-out ponds, with minimal water replacement
}

\author{
Eulalio Arambul-Muñoz ${ }^{1}$, Jesús T. Ponce-Palafox ${ }^{1}$, Raúl Claro De Los Santos ${ }^{2}$ \\ Eugenio Alberto Aragón-Noriega ${ }^{3}$ \\ Guillermo Rodríguez-Domínguez ${ }^{4} \&$ Sergio Gustavo Castillo-Vargasmachuca ${ }^{1}$ \\ ${ }^{1}$ Doctorado en Ciencias Biológico Agropecuarias, Universidad Autónoma de Nayarit \\ Escuela Nacional de Ingeniería Pesquera, Laboratorio de Bioingeniería Costera \\ San Blas, Nayarit, México \\ ${ }^{2}$ Maestría en Ciencias Biológico Agropecuarias, Universidad Autónoma de Nayarit, Escuela Nacional \\ de Ingeniería Pesquera, Laboratorio de Bioingeniería Costera, San Blas, Nayarit, México \\ ${ }^{3}$ Centro de Investigaciones Biológicas del Noroeste, Unidad Sonora Guaymas, Sonora, México \\ ${ }^{4}$ Facultad de Ciencias del Mar, Universidad Autónoma de Sinaloa, Mazatlán, Sinaloa, México \\ Corresponding author: Sergio Gustavo Castillo-Vargasmachuca (sergioc@uan.edu.mx)
}

\begin{abstract}
This work aimed to determine the optimum stocking density of Penaeus vannamei, cultured in a photo-heterotrophic intensive circular system inlined grow-out ponds with minimal water replacement. Five intensive density levels $\left(100,300,500,700\right.$ and $\left.900 \mathrm{ind}^{-3}\right)$ were considered. The water quality measured for the 98 days grow-out period was within the adequate range for $P$. vannamei. TAN, nitrate and total phosphorus water quality were significantly higher $(P<0.05)$ at the higher density. Growth rates and survival decreased as density increased after $300 \mathrm{org} \mathrm{m}^{-3}$. Based on the results of this study, it was found that shrimp grows adequately in high biomass density $\left(99.21 \mathrm{~kg} \mathrm{tank}^{-1}\right)$ and density of $500 \mathrm{ind} \mathrm{m}^{-3}$ in an intensive photo-heterotrophic system with a maximum harvest weight of $10 \mathrm{~g}$.
\end{abstract}

Keywords: Penaeus vannamei; lined tank; intensive growth system; survival; harvest; aquaculture

\section{INTRODUCTION}

In the last decade, the shrimp farming industry in Latin America has had to find for other alternatives for its expansion, mainly due to disease and environmental problems. The most widely used strategies and systems have been use of improved environmentally formulated commercial dry feeds (Mishra et al., 2008), different feed management treatments (Jescovitch et al., 2018), different stocking densities, pond size reduction, partial harvests (Yu \& Leung, 2006), aeration, recirculating aquaculture systems (RAS) (Ray \& Lots, 2017), biofloc (Esparza-Leal et al., 2015) or photo-heterotrophic systems (Moreno-Figueroa et al., 2017).

Managing an intensive culture shrimp system with constant output has been a challenge for producers in recent years (Garza de Yta et al., 2004). The intensive production has been carried out using ponds of concrete, tanks covered with black polyethylene plastic and rectangular and circular shapes. The advantages and disadvantages analysis of using plastic-lined shrimp ponds have been thoroughly described (Moss, 1995), among the advantages are the construction of ponds in soil with poor quality, reduces the time of cultivation, increases the number of crops and reduces infections due to the existence of pathogens in the sediment.

One (grow-out) and two phases (nursery and growout) cultivation strategies have also been employed for the intensive systems. The techniques for the management of the two-phase strategy have been well studied (Garza de Yta et al., 2004). However, there is little data related to the effects of a single phase on the final grow-out of shrimp to marketable size (Samocha 
et al., 2002) in small-scale circular pond shrimp farming. The production output is limited by reduced growth and survival as stocking densities increase $(\mathrm{Yu}$ et al., 2009). Density-dependent growth and survival is a typical response in intensive shrimp culture mainly due to a combination of factors, which include: decrease in the availability of natural food sources and space, an increase in cannibalism, decrease in water quality and accumulation of undesirable sediments (Arnold et al., 2006). For further development of the photo-heterotrophic intensive system in circular lined ponds grow-out to a commercial scale, research on biological, technical and financial feasibility needs to be conducted before implementing this system in a real aquaculture operation. Therefore, the present work was aimed at investigating the performance production and water quality $P$. vannamei postlarvae, reared in a one phase cultivation strategy at different stocking densities in circular plastic-lined ponds in grow-out culture systems.

\section{MATERIALS AND METHODS}

\section{Experimental design}

The experiments were performed in the Coastal Bioengineering Laboratory, of the National School of Fishery Engineering, University of Nayarit, San Blas Nayarit, Mexico $\left(21^{\circ} 29^{\prime} \mathrm{N}, 105^{\circ} 12^{\prime} \mathrm{W}\right)$. The shrimp postlarvae $\left(\mathrm{Pl}_{15}\right)$ used in this study were acquired from a commercial laboratory "Acopio de Larvas y Asesoría en Proyectos S.A. de C.V." located in Matanchen Bay, San Blas, Nayarit. The shrimp postlarvae (mean initial weight $=0.001 \pm 0.002 \mathrm{~g}$ ) were transferred to the experimental tanks, where the experimental design was randomized with five stocking densities per experimental system, with 100 (T100), 300 (T300), 500 (T500), 700 (T700), and 900 (T900) ind $\mathrm{m}^{-3}$. Three replicates were randomly assigned to each stocking density. Shrimp were fed every two hours using feeders (four by tank) with commercial feed maltaCleyton ${ }^{\circledR}(40$ to $25 \%$ crude protein). The feeding rate was 10 to $2 \%$ adjusted daily until the end of the study (98 days).

\section{Shrimp culture systems}

The circular plastic-lined ponds were used to maintain the same water quality in all experimental units. The system included 15 circular tanks of $35 \mathrm{~m}^{3}$ (microcosms) with $6 \mathrm{~m}$ diameter; continuous aeration at a rate of $29 \mathrm{~mL} \mathrm{~s}^{-1}$ was maintained during culture period with four diffusers inside each culture tank. The systems were filled with seawater of salinity 35 , filtered through a sand filter and activated carbon. In all cases, there was no water exchange during the study, only the replacement of loss due to evaporation by adding seawater $\left(0.5 \%\right.$ week $\left.^{-1}\right)$. A commercial probiotic Epicin ${ }^{\circledR}$-Hatcheries was added every week until the end of the trial in each tank $\left(2 \mathrm{~g} \mathrm{~m}^{-3}\right)$, to promote a heterotrophic microbial complex. The probiotic mix contained Bacillus subtilis, Bacillus lincheniformis, Bacillus coagulans, Lactobacillus acidophilus and Saccharomyces cerevisiae. Also, to improve the nitrification process, $10 \%$ of molasses per $\mathrm{kg}$ of food was added per day.

\section{Water quality parameters analyses}

During the study, the water quality was monitored in the experimental tanks. The concentration of dissolved oxygen $\left(\mathrm{DO} ; \mathrm{mg} \mathrm{L}^{-1}\right)$, temperature $\left({ }^{\circ} \mathrm{C}\right), \mathrm{pH}$ and salinity were monitored every two hours utilizing a multiparameter analyzer (model Pro 20, YSI Inc., Yellow Springs, OH, USA). The concentrations of total ammonium nitrogen-TAN $\left(\mathrm{mg} \mathrm{L}^{-1}\right)$, nitrite- $\mathrm{N}\left(\mathrm{mg} \mathrm{L}^{-1}\right)$, nitrate- $\mathrm{N}\left(\mathrm{mg} \mathrm{L}^{-1}\right)$ and orthophosphate-P $\left(\mathrm{mg} \mathrm{L}^{-1}\right)$ were measured weekly, according to the methods recommended by UNESCO (1983).

\section{Growth of shrimp}

The biometrics was performed weekly, weighing 60 shrimp from each experimental tank individually using a digital balance (precision 0,001 g, Ohaus Scout ${ }^{\circledR}$ ). At the end of the study, all the shrimp were weighed and counted to evaluate final weight $(\mathrm{FW})$, specific growth rate (SGR), survival and feed conversion ratio (FCR). The SGR (\% weight increase $\mathrm{d}^{-1}$ ) was calculated according to Ricker (1979), and the FCR according to Hari et al. (2004).

\section{Production planning of shrimp}

The production plan consisted of estimating a minimum commercial harvest size of $10 \mathrm{~g}$ in a circular lined ponds grow-out (Table 3), in order to know the minimum time of harvest in each of the densities used for the experiment in this work, for which information growth and density obtained was used during our study at 14 weeks of culture. The production scheme was developed on the real condition of the shrimp industry in Mexico.

\section{Statistical analyses}

The homoscedasticity and normality of the data were verified by Leven test and Kolmogorov-Smirnov test, respectively. The survival (\%) data were analyzed using a one-way ANOVA (Zar, 1996). The recorded data, at different stocking densities, was analyzed with one-way analysis of variance (ANOVA) and the Tukey's test (Sokal \& Rohlf, 1969) when a significant difference was detected in the treatments of each density (IBM SPSS Statistics V20.0.0 Copyright IBM 
Corporation 1989, 2011, USA). The differences were considered significant at 95\%. Correlations and regression (as well as extrapolation and interpolation) between production, growth rate, SGR, biomass and survival parameters were tested for significance in the Harrell Miscellaneous, R package version 3.17-3 (Harrell \& Dupont, 2016).

\section{RESULTS}

\section{Water quality}

The water temperature, $\mathrm{DO}, \mathrm{pH}$ and salinity concentrations did not show any significant difference $(P>$ 0.05 ) among different stocking densities (Table 1). TAN concentration in T700 and T900 were significantly higher compared to the other treatments $(P<$ $0.05)$. Nitrite concentrations did not show any difference among stocking densities $(P>0.05)$, and nitrate and total phosphorus concentrations in T500, T700 and T900 were significantly higher than those in T100 and T300 $(P<0.05)$.

\section{Growth performance of shrimp}

The average weight and survival percentage of shrimp at harvest $(11.93 \pm 0.53 \mathrm{~g}$ and $93.25 \%$, respectively), were significantly higher $(P<0.05)$ at the lowest stocking density $\left(100\right.$ ind $\left.\mathrm{m}^{-3}\right)$ compared to 98 days (Table 2).

Final weight, growth rate and SGR in the highest densities T700 and T900 were the lowest: 4.28 to 5.40 $\mathrm{g}, 0.31$ to $0.39 \mathrm{~g}^{\text {week }}{ }^{-1}$ and 8.90 to $9.14 \% \mathrm{~d}^{-1}$, respectively. The shrimp biomass and production in T500 were significantly higher compared to the rest of the treatments $(P<0.05)$, and reached $99.21 \mathrm{~kg} \mathrm{tank}^{-1}$ and $2.83 \mathrm{~g} \mathrm{~m}^{-3}$, respectively. FC was significantly lower in T100, T300, and T500 (1.12 to 1.23). Overall, it was found a tendency to present a greater uniformity in the mean weight of the shrimp in the treatments with lower density T100 and T300.

\section{Production scheme of shrimp}

Based on a production scheme in the shrimp circular lined ponds farm presented during this study, it was generated a model of production considering minimum size of $10 \mathrm{~g}$ at five stocking densities (Table 3 ).

The minimum commercial size of $10 \mathrm{~g}$ was obtained in the shortest time (60 days) at the 100 ind $\mathrm{m}^{-3}$ treatment. The highest FCR $(2,2)$, production $(4,5 \mathrm{~kg}$ $\mathrm{m}^{-3}$ ) and biomass harvest $\left(157,5 \mathrm{~kg} \mathrm{tank}^{-1}\right)$ were obtained in the 900 ind $\mathrm{m}^{-3}$ treatment, but in the time of 120 days. However, when considering only the technical factor, an inflection point found at the density of 500 ind $\mathrm{m}^{-3}$, when biomass is related to survival. At the point of inflection, the increase in density decreases the rate of biomass harvest and decreases survival.

\section{DISCUSSION}

\section{Water quality}

The water quality measured during the 14-wk grow-out period was within the adequate range for the growth and survival of Penaeus vannamei (Lin \& Chen, 2001, 2003; Tsai \& Chen, 2002; Boyd, 2015). In general, a significant increases $(P<0.05)$ in the concentrations of TAN, nitrate-nitrogen and total phosphorus in T700 and T900 treatments. The dissolved oxygen level in all treatments was above $5 \mathrm{mg} \mathrm{L}^{-1}$, which is considered adequate for growth (Garza de Yta et al., 2004). There was a non-significant tendency $(P>0.05)$ to decrease dissolved oxygen as stocking density increases in T700 and T900 treatments; this is associated with increased feed intake and FCR, and has already been reported in fish and shrimp (Arnold et al., 2006; Person-Le Ruyet et al., 2008). TAN remained below $1.39 \mathrm{mg} \mathrm{L}^{-1}$, which does not affect shrimp growth (Lin \& Chen, 2001; Arnold et al., 2006), and was significantly higher ( $P<$ 0.05 ) at the higher densities (T700 and T900), an effect reported by Arnold et al. (2009) in shrimp. A higher concentration of nitrates and phosphorus was also found in T700 and T900 treatments, which could be associated with higher nitrification and heterotrophic activity and suspended biofloc in the water column (Avnimelech, 2006, 2012). Besides, the presence of higher nitrate concentration was an indicator that aerobic nitrification was occurring (Vinatea et al., 2010). The use of molasses and probiotics in the intensive systems used showed that even in high densities $\left(900\right.$ org $\mathrm{m}^{-3}$ ), inorganic nitrogen and total phosphorus were reduced, which has already been demonstrated by Avnimelech (1999), because the photo-heterotrophic system promotes the development of microbial communities (Ray et al., 2011). The C:N ratio remained at 20:1 ratio, however, as the experiment progressed and the organisms have developed, the concentrations of nitrogen compounds increased, and it was necessary to add an external carbon source (Molasses). The calculations to determine the amount of molasses were according to Ebeling et al. (2006), which allowed the $\mathrm{C}: \mathrm{N}$ ratio to remain 20:1 ratio throughout the crop, adjusting when necessary.

\section{Growth of shrimp}

In general, different aquaculture systems have been used to improve water quality and reduce the stress of shrimp in intensive systems, with the consequent increase in the growth rate, among which are the recir- 
Table 1. Variations of water quality parameters (mean \pm SD) in the circular lined ponds used for the rearing of Penaeus vanname $i$ at different densities for 98 days period (values with the same superscript within the same row are not significantly different at $P<0.05$ ).

\begin{tabular}{|c|c|c|c|c|c|}
\hline Treatment & $\begin{array}{c}\text { T100 } \\
\left(100 \text { ind } \mathrm{m}^{-3}\right)\end{array}$ & 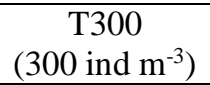 & $\begin{array}{c}\mathrm{T} 500 \\
\left(500{\left.\text { ind } \mathrm{m}^{-3}\right)}^{-3}\right.\end{array}$ & $\begin{array}{c}\text { T700 } \\
\left(700{\left.\text { ind } \mathrm{m}^{-3}\right)}\right.\end{array}$ & $\begin{array}{c}\text { T900 } \\
\left(900{\left.\text { ind } \mathrm{m}^{-3}\right)}^{-}\right.\end{array}$ \\
\hline Temperature $\left({ }^{\circ} \mathrm{C}\right)$ & $27.02 \pm 2.4^{\mathrm{a}}$ & $26.90 \pm 2.3^{\mathrm{a}}$ & $27.18 \pm 2.2^{\mathrm{a}}$ & $27.14 \pm 2.2^{\mathrm{a}}$ & $27.16 \pm 2.1^{\mathrm{a}}$ \\
\hline Dissolved oxygen $\left(\mathrm{mg} \mathrm{L}^{-1}\right)$ & $6.38 \pm 0.62^{\mathrm{a}}$ & $6.37 \pm 0.52^{\mathrm{a}}$ & $6.20 \pm 0.29^{\mathrm{a}}$ & $6.19 \pm 0.74^{\mathrm{a}}$ & $6.18 \pm 0.78^{a}$ \\
\hline Salinity $\left(\mathrm{g} \mathrm{L}^{-1}\right)$ & $33.59 \pm 1.21^{\mathrm{a}}$ & $33.64 \pm 1.25^{\mathrm{a}}$ & $33.62 \pm 1.26^{\mathrm{a}}$ & $33.65 \pm 1.24^{\mathrm{a}}$ & $33.61 \pm 1.23^{\mathrm{a}}$ \\
\hline $\mathrm{pH}$ & $8.07 \pm 0.18^{\mathrm{a}}$ & $8.02 \pm 0.23^{\mathrm{a}}$ & $7.99 \pm 0.25^{\mathrm{a}}$ & $7.89 \pm 0.27^{\mathrm{a}}$ & $7.81 \pm 0.29^{\mathrm{a}}$ \\
\hline TAN $\left(\mathrm{mg} \mathrm{L}^{-1}\right)$ & $1.07 \pm 0.24^{\mathrm{c}, \mathrm{b}}$ & $1.10 \pm 0.30^{\mathrm{b}}$ & $1.17 \pm 0.23^{b}$ & $1.37 \pm 0.31^{\mathrm{a}}$ & $1.39 \pm 0.35^{\mathrm{a}}$ \\
\hline Nitrite-nitrogen & $0.042 \pm 0.02^{\mathrm{a}}$ & $0.048 \pm 0.02^{\mathrm{a}}$ & $0.050 \pm 0.02^{\mathrm{a}}$ & $0.051 \pm 0.04^{\mathrm{a}}$ & $0.054 \pm 0.06^{\mathrm{a}}$ \\
\hline e-nitrogen $\left(\mathrm{mg} \mathrm{L}^{-1}\right)$ & $1.27 \pm 0.22^{b}$ & $1.47 \pm 0.52^{b}$ & $1.50 \pm 0.7^{b}$ & $1.67 \pm 0.82^{\mathrm{a}}$ & $1.69 \pm 0.84^{\mathrm{a}}$ \\
\hline Total phosphorus (mg L $\left.{ }^{-1}\right)$ & $1.56 \pm 0.28^{\mathrm{b}}$ & $1.58 \pm 0.79^{\mathrm{b}}$ & $1.59 \pm 0.25^{\mathrm{b}}$ & $1.66 \pm 0.22^{\mathrm{a}}$ & $1.69 \pm 0.33^{\mathrm{a}}$ \\
\hline
\end{tabular}

Table 2. Growth of white shrimp Penaeus vannamei with different biomass densities in a circular lined ponds grow-out, with minimal water replacement (mean \pm SD) after 98 days (values with the same superscript within the same row are not significantly different at $P<0.05$ ).

\begin{tabular}{|c|c|c|c|c|c|}
\hline Treatment & $\begin{array}{c}\text { T100 } \\
\left(100 \text { ind } \mathrm{m}^{-3}\right) \\
\end{array}$ & $\begin{array}{c}\text { T300 } \\
\left(300 \text { ind } \mathrm{m}^{-3}\right) \\
\end{array}$ & $\begin{array}{c}\text { T500 } \\
\left(500{\left.\text { ind } \mathrm{m}^{-3}\right)}^{-}\right.\end{array}$ & $\begin{array}{c}\text { T700 } \\
\left(700 \text { ind } \mathrm{m}^{-3}\right)\end{array}$ & $\begin{array}{c}\text { T900 } \\
\left(900 \text { ind } \mathrm{m}^{-3}\right)\end{array}$ \\
\hline Final $\mathrm{w}$ & $11.93 \pm 0.41^{\mathrm{a}}$ & $9.73 \pm 0.53^{b}$ & $7.65 \pm 0.66^{\mathrm{c}}$ & $5.40 \pm 0.87^{\mathrm{d}}$ & $4.28 \pm 0.80^{\mathrm{d}}$ \\
\hline $\mathrm{Fe}$ & $1.12 \pm 0$. & $1.15 \pm 0.15^{\mathrm{a}}$ & $1.23 \pm 0.11^{\mathrm{ab}}$ & $1.44 \pm 0.08^{\mathrm{b}}$ & $1.50 \pm 0.13^{\mathrm{b}}$ \\
\hline Gro & $0.85 \pm 0.26^{\mathrm{a}}$ & $0.70 \pm 0.27^{\mathrm{a}}$ & $0.55 \pm 0.21^{\mathrm{b}}$ & $0.39 \pm 0.13^{b}$ & $0.31 \pm 0.22^{b}$ \\
\hline $\mathrm{Sp}$ & $9.99 \pm 0.13^{\mathrm{a}}$ & $9.77 \pm 0.08^{\mathrm{ab}}$ & $9.51 \pm 0.10^{\mathrm{b}}$ & $9.14 \pm 0.28^{c}$ & $8.90 \pm 0.31^{\mathrm{c}}$ \\
\hline Bior & $38.94 \pm 1.98^{\mathrm{e}}$ & $93.38 \pm 2.31^{\mathrm{b}}$ & $99.21 \pm 1.41^{\mathrm{a}}$ & $86.95 \pm 1.78^{c}$ & $75.12 \pm 1.82^{\mathrm{d}}$ \\
\hline Proc & $1.11 \pm 0.03^{\mathrm{d}}$ & $2.67 \pm 0.04^{b}$ & $2.83 \pm 0.06^{\mathrm{a}}$ & $2.48 \pm 0.08^{\mathrm{b}}$ & $2.15 \pm 0.09^{c}$ \\
\hline Survival (\% & $93.2^{\mathrm{a}}$ & $91.4^{\mathrm{a}}$ & $74.0^{\mathrm{b}}$ & $65.7^{\mathrm{c}}$ & $55.7^{\mathrm{d}}$ \\
\hline
\end{tabular}

culating aquaculture system (RAS), artificial substrates, biofloc technology (BFT) and photoheterotrophic system. Therefore, in this work, the purpose was to demonstrate whether the photo-heterotrophic system culture conditions are suitable for high shrimp densities, in intensive grow-out systems in circular lined ponds with little water exchange and the strategy of growing one phase to minimum commercial size $(10 \mathrm{~g})$. The research showed that the photoheterotrophic system reduces the estimated stress level of the shrimp by a high growth rate of shrimp (0.55$0.85 \mathrm{~g}$ week $^{-1}$ ) at densities 100 to 500 ind $\mathrm{m}^{-3}$ until reaching the commercial size and good water quality. The growth rate of the 100 ind $\mathrm{m}^{-3}\left(0.85 \mathrm{~g} \mathrm{week}^{-1}\right)$ treatment was close to the results reported by MorenoFigueroa et al. (2017) in photo-heterotrophic hypersaline systems in lined ponds $\left(0.95 \mathrm{~g} \mathrm{week}^{-1}\right)$ showing that the photo-heterotrophic grow-out system in circular lined ponds increases the carrying capacity (Avnimelech, 2012) up to 500 ind $\mathrm{m}^{-3}$. It was found to be feasible to grow white shrimp to commercial size for 98 days. Under these conditions, growth rates were within the reported figures for the species $(0.33$ to 0.95 $\mathrm{g} \mathrm{week}^{-1}$ ) in intensive culture (Williams et al., 1996; Davis \& Arnold, 1998). The biomass densities did not appear to affect FCR, GR and SGR of juveniles shrimp up to densities 500 ind $\mathrm{m}^{-3}$. The $\mathrm{FW}$ in the $900 \mathrm{ind} \mathrm{m}^{-3}$ treatment was $64.1 \%$ lower than in shrimp from the 100 ind $\mathrm{m}^{-3}$ treatment. The increase in FCR with increasing stocking density may due to increased feed intake values and/or decreased in feed efficiency.

In the photo-heterotrophic intensive grow-out system, in circular lined ponds, similar to those obtained by Schveitzer et al. (2013) in tanks with artificial substrates (92.6\%), it was found that if the size and number of shrimp for stocking are not constraints, the maximum number of juveniles above $90 \%$ survival from a minimum rearing space was achieved at a stocking density of 300 ind $\mathrm{m}^{-3}$. At densities around 500 ind $\mathrm{m}^{-3}$ survivals were $23.6 \%$ lower than those determined in RAS systems with settling tank and with fractionator (Samocha et al., 2010). The lower survival in the 700 and 900 ind $\mathrm{m}^{-3}$ may be due to the crowding that led to stress in the shrimp and made them more susceptible to pathogenic microorganisms, as was found by Schveitzer et al. (2013) in high shrimp densities in intensive systems. In the T700 to T900 the increase in stocking density from 700 to 900 ind $\mathrm{m}^{-3}$ was accompanied by a reduction in the biomass harvest due to low survival and growth. This response in high 
Table 3. Estimated production to produce $10 \mathrm{~g}$ shrimp at harvest at a different density in a circular lined ponds grow-out.

\begin{tabular}{|c|c|c|c|c|c|}
\hline Treatment & $\begin{array}{c}\text { T100 } \\
\left(100 \text { ind } \mathrm{m}^{-3}\right) \\
\end{array}$ & $\begin{array}{c}\text { T300 } \\
\left(300 \text { ind } \mathrm{m}^{-3}\right)\end{array}$ & $\begin{array}{c}\text { T500 } \\
\left(500{\left.\text { ind } ~^{-3}\right)}^{~}\right.\end{array}$ & $\begin{array}{c}\text { T700 } \\
\left(700 \text { ind } \mathrm{m}^{-3}\right)\end{array}$ & $\begin{array}{c}\text { T900 } \\
\left(900{\left.\text { ind } \mathrm{m}^{-3}\right)}^{2}\right.\end{array}$ \\
\hline Culture time (days) & 60 & 75 & 90 & 110 & 120 \\
\hline Stocking (ind tank ${ }^{-1}$ ) & 3,500 & 10,500 & 17,500 & 24,500 & 31,500 \\
\hline Feed conversion ratio & 1.2 & 1.4 & 1.8 & 2.0 & 2.2 \\
\hline Growth rate $\left(\mathrm{g}\right.$ week $\left.{ }^{-1}\right)$ & 1.3 & 1.0 & 0.8 & 0.7 & 0.6 \\
\hline Specific growth rate $\left(\% \mathrm{~d}^{-1}\right)$ & 15.4 & 12.3 & 10.2 & 8.4 & 7.7 \\
\hline Production $\left(\mathrm{kg} \mathrm{m}^{-3}\right)$ & 0.86 & 2.4 & 3.75 & 4.2 & 4.5 \\
\hline Biomass harvest $\left(\mathrm{kg} \operatorname{tank}^{-1}\right)$ & 30.0 & 84.0 & 131.3 & 147.0 & 157.5 \\
\hline Survival (\%) & 85 & 80 & 75 & 60 & 50 \\
\hline
\end{tabular}

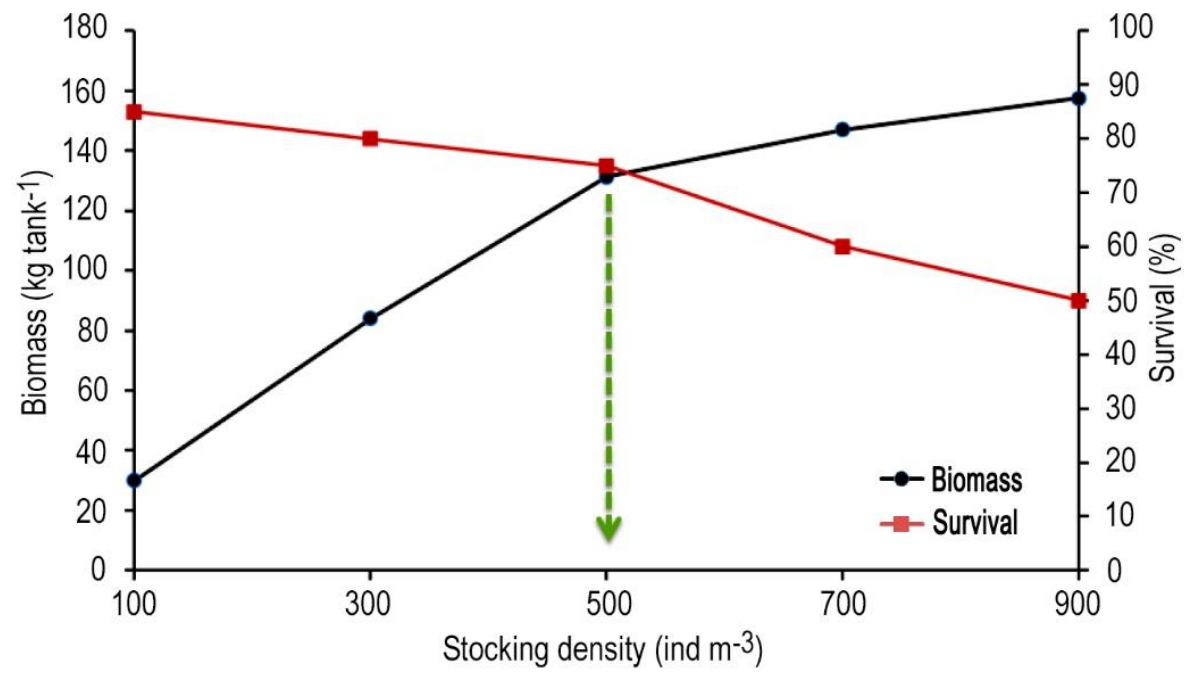

Figure 1. Relationship between biomass and survival of shrimp at different densities, in circular grow-out, lined ponds.

densities in intensive shrimp systems has suggested that the crowding causes stress, and affects the shrimp performance (Otoshi et al., 2006).

\section{Production scheme of shrimp}

A production model was designed and proposed for the small producer from a production scheme in the growout system with circular lined ponds documented during this study, where production estimation of white shrimp culture, using photo-heterotrophic intensive system with minimal water replacement, was assumed to obtain organisms of commercial size $10 \mathrm{~g}$ in a short time with the minimum profitable survival. The production model showed that stocking density increases culture time, stocking, FCR, production and biomass harvest (Table 3), and decreases growth rate, SGR and survival. However, when the biomass and survival curves were shown, a point of inflection was found to be descendant in survival and ascending in biomass at 500 ind $\mathrm{m}^{-3}$ (Fig. 1). A condition in which the dense-dependent effect begins to affect the survival and shrimp growth, which is reached after 90 days of cultivation with $131.3 \mathrm{~kg}$ tank $^{-1}$. Additionally, shrimp growth and mortality suggest that the cost-effective production would be lower at a density of 500 ind $\mathrm{m}^{-3}$ compared to 900 ind $\mathrm{m}^{-3}$. Since the extra production time (30 days) would substantially increase costs associated with feed, labor and energy when applied to commercial-scale operations.

\section{CONCLUSIONS}

It was found in this study that production of $2.83 \mathrm{~g} \mathrm{~m}^{-3}$ or stocking density of 500 ind $\mathrm{m}^{-3}$ (T500) could be acceptable for juvenile shrimp reared in a photoheterotrophic intensive system in circular grow-out lined ponds, with minimal water replacement. The intensive production system developed in this work could be applied to a small shrimp farms at commercial scale, as one phase of postlarvae to harvested biomass, reaching the minimum size of $10 \mathrm{~g}$ at 90 days. Additional studies are required to confirm the effects of stocking density on larger juveniles to produce advanced stocks $(>10 \mathrm{~g})$ in the different seasons of the year. 


\section{REFERENCES}

Avnimelech, Y. 1999. Carbon/nitrogen ratio as a control element in aquaculture systems. Aquaculture, 176: 227-235.

Avnimelech, Y. 2006. Bio-filters: the need for a new comprehensive approach. Aquacultural Engineering, 34: 172-178.

Avnimelech, Y. 2012. Biofloc technology. A practical guide book. The World Aquaculture Society, Louisiana.

Arnold, S.J., Coman, F.E., Jackson, C.J. \& Groves, S.A. 2009. High-intensity, zero water-exchange production of juvenile tiger shrimp, Penaeus monodon: an evaluation of artificial substrates and stocking density. Aquaculture, 293: 42-48.

Arnold, S.J., Sellars, M.J., Crocos, P.J. \& Coman, G.J. 2006. Intensive production of juvenile tiger shrimp Penaeus monodon: an evaluation of stocking density and artificial substrates. Aquaculture, 261: 890-896.

Boyd, C.E. 2015. Water quality: an introduction. Springer, New York.

Davis, D.A. \& Arnold, C.R. 1998. The design, management, and production of a recirculating raceway system for the production of marine shrimp. Aquacultural Engineering, 17: 193-211.

Ebeling, J.M., Timmons, M.B. \& Bisogni, J.J., 2006. Engineering analysis of the stoichiometry of photoautotrophic, autotrophic, and heterotrophic control of ammonia-nitrogen in aquaculture in aquaculture production systems. Aquaculture, 257: 346-358.

Esparza-Leal, H.M., Pereira-Cardozo, A. \& Wasielesky Jr., W. 2015. Performance of Litopenaeus vannamei postlarvae reared in indoor nursery tanks at high stocking density in clear-water versus biofloc system. Aquacultural Engineering, 68: 28-34.

Garza de Yta, A., Rouse, D.B. \& Davis, D.A. 2004. Influence of nursery period on the growth and survival of Litopenaeus vannamei under pond production conditions. Journal of the World Aquaculture Society, 35(3): 357-365.

Hari, B., Kurup, B.M., Varghese, J.T., Schrama, J.W. \& Verdegem, M.C.J. 2004. Effects of carbohydrate addition on production in extensive shrimp culture systems. Aquaculture, 241: 179-194.

Harrell Jr., F.E. \& Dupont, C. 2016. Hmisc: Harrell miscellaneous. $\mathrm{R}$ package version 3.17-3. https:// CRAN.R-project.org/package=Hmisc. Reviewed: 25 May 2018.

Jescovitch, L.N., Ullman, C., Rhodes, M. \& Davis, D.A. 2018. Effects of different feed management treatments on water quality for Pacific white shrimp Litopenaeus vannamei. Aquaculture Research, 49(1): 526-531.

Lin, Y.C. \& Chen, J.C. 2001. Acute toxicity of ammonia on Litopenaeus vannamei Boone juveniles at different salinity levels. Journal of Experimental Marine Biology and Ecology, 259: 109-119.

Lin, Y.C. \& Chen, J.C. 2003. Acute toxicity of nitrite on Litopenaeus vannamei (Boone) juveniles at different salinity levels. Aquaculture, 224(1-4): 193-201.

Mishra, J.K., Samocha, T.M., Patnaik, S., Speed, M., Gandy, R.L. \& Ali, A.M. 2008. Performance of an intensive nursery system for the Pacific white shrimp, Litopenaeus vannamei, under limited discharge condition. Aquacultural Engineering, 38: 2-15.

Moreno-Figueroa, L.D., Naranjo-Paramo, J., HernándezLlamas, A., Vargas-Mendieta, M., HernándezGurrola, J.A. \& Villarreal-Colmenares, H. 2017. Performance of a photo-heterotrophic, hypersaline system for intensive cultivation of white leg shrimp (Litopenaeus vannamei) with minimal water replacement in lined ponds using a stochastic approach. Aquaculture Research, 49(1): 57-67.

Moss, S.M. 1995. Production of growth-enhancing particles in a plastic-lined shrimp pond. Aquaculture, 132: 253-260.

Otoshi, C.A., Montgomery, A.D., Matsuda, E.M. \& Moss, S.M. 2006. Effects of artificial substrate and water source on the growth of juvenile Pacific white shrimp, Litopenaeus vannamei. Journal of the World Aquaculture Society, 37: 210-213.

Person-Le Ruyet, J., Labbé, L., Le Bayon, N., Sévère, A., Le Roux, A., Le Delliou, H. \& Quéméner, L. 2008. Combined effects of water quality and stocking density on welfare and growth of rainbow trout (Oncorhynchus mykiss). Aquatic Living Resources, 21: 185-195.

Ray, A.J. \& Lotz, J.M. 2017. Shrimp (Litopenaeus vannamei) production and stable isotope dynamics in clear-water recirculating aquaculture systems versus biofloc systems. Aquaculture Research, 48: 43904398.

Ray, A.J., Dillon, K.S. \& Lotz, J.M. 2011. Water quality dynamics and shrimp (Litopenaeus vannamei) production in intensive, mesohaline culture systems with two levels of biofloc management. Aquacultural Engineering, 45: 127-136.

Ricker, W.E., 1979. Growth rates and models. In: Hoar, W.S., Randall, D.J. \& Brett, J.R. (Eds.). Fish physiology, vol. VIII. Bioenergetics, and growth. Academic Press, New York, pp. 677-743.

Samocha, T.M., Wilkenfeld, J.S., Morris, T.C., Correia, E.S. \& Hanson, T. 2010. Intensive raceways without water exchange analyzed for white shrimp culture. Global Aquaculture Advocate, 13(4): 22-24.

Samocha, T.M., Hamper, L., Emberson, C.R., Davis, A.D., McIntosh, D., Lawrence, A.L. \& Van Wyk, P.M. 2002. Review of some recent developments in sustainable shrimp farming practices in Texas, 
Arizona, and Florida. Journal of Applied Aquaculture, 12(1): 1-42.

Schweitzer, R., Arantes, R., Costódio, P.F.S., Do Espírito Santo, C.M., Arana, L.V., Seiffert, W.Q. \& Andreatta, E.R. 2013. Effect of different biofloc levels on microbial activity, water quality and performance of Litopenaeus vannamei in a tank system operated with no water exchange. Aquacultural Engineering, 56: 5970.

Sokal, R.R. \& Rohlf, F.J. 1969. Biometry: the principles and practices of statistics in biological research. W.H. Freeman, New York.

Tsai, S.J. \& Chen, J.C. 2002. Acute toxicity of nitrate on Litopenaeus vannamei Boone juveniles at different salinity levels. Aquaculture, 213: 163-170.

Vinatea, L., Galvez, A.O., Browdy, C.L., Stokes, A., Venero, J., Haveman, J., Lewis, B.L., Lawson, A., Shuler, A. \& Leffler, J.W. 2010. Photosynthesis, water respiration and growth performance of Litopenaeus vannamei in a super-intensive raceway culture with zero water exchange: Interaction of water quality variables. Aquacultural Engineering, 42: 17-24.

Received: 3 August 2018; Accepted: 17 January 2019
United Nations Educational, Scientific and Cultural Organization (UNESCO). 1983. Chemical methods for use in marine environmental monitoring. Intergovernamental Oceanographic Commission, Manual and Guides, Paris, 53 pp.

Williams, A.S., Davis, D.A. \& Arnold, C.R. 1996. Density-dependent growth and survival of Penaeus setiferus and Penaeus vannamei in a semi-closed recirculating system. Journal of the World Aquaculture Society, 27: 107-112.

Yu, R., \& Leung, P.S. 2006. Optimal partial harvesting schedule for aquaculture. Marine Resource Economics, 21: 301-315.

Yu, R., Leung, P.S. \& Bienfang, P. 2009. Modeling partial harvesting in intensive shrimp culture: a network-flow approach. European Journal of Operational Research, 193: 262-271.

Zar, J.H. 1996. Biostatistical analysis. Prentice Hall, New Jersey. 